\title{
Granice wspólnoty albo gra z cieniem: brak, sekret i duch przyjaźni w antropologii Plessnera i Derridy
}

DOI: http://dx.doi.org/10.12775/RF.2017.024

\begin{abstract}
Wiek pierwszy to era poddaństwa, drugi to wpólnota synów, trzeci to era wolności. Pierwszy upływa pod znakiem lęku, drugi pod znakiem wiary, trzeci pod znakiem miłości. W pierwszym wszyscy są niewolnikami, w drugim wszyscy są wolni, zaś w trzecim wszyscy zostają przyjaciółmi.

Ernst Benz, Ecclesia spiritualis. Kirchenidee und Geschichtstheologie der franziskanischen Reformation
\end{abstract}

Wydawałoby się, że umieszczenie obok siebie Plessnera i Derridy to spotkanie niemożliwe albo przynajmniej nieprawdopodobne - jak to słynne zetknięcie maszyny do szycia z parasolem na stole operacyjnym, które wymyślił patron surrealistów de Lautréamont. W eseju tym spróbuję jednak dowieść, że obaj myśliciele mają część wspólna, która takie spotkanie umożliwia: obu można bowiem potraktować jako filozofów wyrastających z dziedzictwa Johanna Gottfrieda Herdera, który pierwszy zdefiniował człowieka jako Mängelwesen, istotę wybrakowaną i neoteniczna, na zawsze pozostającą $\mathrm{w}$ stanie niedopełnienia i niedojrzałości.

Helmuth Plessner to samozadeklarowany następca Herdera, uprawiający wprost gatunek zwany niemiecką antropologią filozoficzną Derrida natomiast to nade wszystko dekonstruktor wyrastający z tradycji Heideggerowskiej, która na antropologii filozoficznej nie zostawiła suchej nitki, lecz także, choć bardziej pośrednio, krytyczny myśliciel ludzkiego braku. W ostatnich seminariach Derridy wątek wybrakowania 
pojawia się explicite, fundując wielką linię "filozofów antropogenezy": od Kartezjusza, przez Kanta, Hegla i Heideggera, po Kojève’a i Lacana. To wprawdzie nie Herder, lecz Jacques Lacan figuruje w nich jako autor sentencji, że „zwierzęciu brakuje braku" ${ }^{1}$ - lecz zarys doktryny pozostaje ten sam i choć Derrida odnosi się do niej nieufnie, wyczuwając w Lacanowskim ujęciu nadmiar „pogardy dla zwierzęcości”, to podejmuje motyw różnicy antropologicznej, tyle że na sposób dekonstrukcyjny. Dla Derridy brak nie jest podstawą dla ludzkiej różnicy jako wyższości. Przeciwnie, brak czyni człowieka istotą szczególnie narażoną na wszelkie ryzyka egzystencjalne, sprawiając, że „nigdy nie nauczy się żyć” ${ }^{2}$; że na zawsze pozostanie dla siebie zagadką i problemem, nieusuwalnym brakiem samowiedzy i rozwiązania. Jednocześnie jednak to właśnie ten brak - z pozoru tak dotkliwy - okazuje się sednem indywiduacji. „Każdy inny może być całkiem innym" ${ }^{3}$ tylko dlatego, że każdy musi radzić sobie z kondycją wybrakowania tylko na swój własny sposób. Brak zatem to także "sekret”: negatywność każdej ludzkiej istoty, która nie może wyjść na jaw - ale także coś nieudzielalnie własnego, na czym zasadza się „inność każdego innego," jego prawo do pojedynczości.

Spotkanie Plessnera z Derridą nie jest więc aż tak surrealne. Obu filozofów łączy, by posłużyć się idiomem Derridy, „upodobanie do se$\mathrm{kretu}^{\prime 4}$ : upodobanie, ponieważ w owej sekretności i skrytości jako braku ujawnienia widzą oni kondycję pozytywną regulującą relację między jednostką a wspólnotą.

\section{Światto-cienie wspólnoty}

W napisanej w latach trzydziestych ubiegłego wieku książce pt. Grenzen der Gemeinschaft Plessner, jeden z współtwórców niemieckiej antropologii filozoficznej, stawia tezę, że istota ludzka nie może żyć w stanie pełnego uspołecznienia. Posiłkując się znaną koncepcją Kanta o apore-

1 Zdanie to pada w: J. Lacan, Ecrits, Editions de Seuil, Paris 1966, s. 819, Derrida zaś komentuje: „Tym, czego brakuje zwierzęciu, jest właśnie brak, dzięki któremu człowiek staje się suwerennym podmiotem języka... Ta suwerenność to wyższość człowieka nad bestia, nawet jeśli wyższość ta opiera się na uprzywilejowaniu braku bądź defektu, wynikających ze zbyt wczesnych narodzin. Zwierzęciu nade wszystko brakuje braku": J. Derrida, The Beast and the Sovereign, vol. 1, przeł. G. Bennington, The University of Chicago Press, Chicago 2009, s. 125, 132.

2 To parafraza angielskiego tytułu ostatniego wywiadu, jakiego udzielił Derrida: J. Derrida, Learning to Live Finally. The Last Interview, przeł. P.-A. Brault, M. House, New York 2011.

3 J. Derrida, Sauf le nom, Gallilee, Paris 2006, p. 92, / On the Name, przeł. J. P. Leavey, Stanford University Press, Stanford 1995, s. 74.

4 Por. tytuł wywiadu udzielonego Maurizio Ferrarisowi: A Taste for the Secret, Polity Press, London 2001. Odtąd w tekście jako TfS. 
tycznej - „towarzysko-nietowarzyskiej” - naturze człowieka, Plessner, ten najbardziej liberalny z kręgu niemieckich antropologów, dokonuje krytyki idei radykalnej communitas, popularnej zarówno wówczas, jak i dziś w kręgach rousseańskiej lewicy jako miejsca nie do życia. Lebenswelt człowieka, mówi Plessner, nie może być w pełni oświetloną scena, w której znikają wszystkie sekrety; zasada pełnego i spontanicznego uczestnictwa we wspólnocie, wymagająca od każdego uczestnika całkowitej przejrzystości, zabija jednostkę jako taką. Zabija ją najpierw symbolicznie, uniemożliwiając jej indywiduację, a następnie - a historia dostarczyła wielu dowodów takiego następstwa - całkiem realnie, doprowadzając do czystek, w trakcie których wspólnota oczyszcza się ze wszystkiego, co obce i niejednorodne: co wciąż stawia opór pełnemu prześwietleniu. Jeśli więc indywidualny podmiot ma przetrwać, musi zostać otoczony ochronną barierą cienia; więcej jeszcze, ciągnie Plessner, trzeba pozwolić mu na pewien brudek prywatności. Oślepiony pełnią uczestnictwa, prześwietlony na wylot i oczyszczony ze wszystkich swoich małych "akcentów dewiacji" - podmiot jednostkowy roztapia się w całości. Ażeby więc mógł utrzymać swoje pojedyncze granice, musi narzucić granice wspólnocie, ograniczyć jej roszczenia pod swoim adresem, odciąć się od niej w Kantowskim „nietowarzyskim” geście, uodpornić na szantaż partycypacji.

Używając metafory światła, Plessner wpada na ten sam trop co młody Marks w swoich notatkach do doktorskiej rozprawy o epikureizmie, choć radykalnie odmienia jego wymowę. Marks, już wtedy domagając się nadejścia społeczeństwa komunistycznego, wyobraża je sobie w postaci wszechjasnego słońca, które w końcu zaleje półmrok milionów mieszczańskich „lampek prywatności”. Społeczeństwo burżuazyjne wydaje mu się wieczną noca, którą rozświetlają tylko małe prywatne światełka i po której krąży „nocna straż” pilnująca, by ta prywatna wolność nie wylała się na ulicę, czyli w sferę publiczną. A jako takie stanowi ono anomalię w historii ludzkości, która przedtem żyła - i jeszcze żyć będzie - pod jednym słońcem, emanującym jednym, publicznym i powszechnym, światłem. W notesie szóstym pisze: „Kiedy to uniwersalne słońce zachodzi, ćmy zlatują się do światła małych lamp prywatności" W trzecim zaś porównuje ową ćmę, czyli nowożytnego mieszczanina, do małej nędznej istoty, która „krąży tylko w obrębie własnej skóry” i na którą Duch - heglowski duch wspólnoty - „nałożył anatemę" ${ }^{\prime 6}$. Metafora uniwersalnego słońca, która nadaje ton marksowskiej filozofii, pociągając za jej pojęciowe sznurki, sugeruje tu cały ciąg pozytywnych skojarzeń: życiodajną energię, z której jednostka korzysta w chwili, w której

5 Cyt. za E. Fischer, How to Read Karl Marx, przeł. A. Bostock, Monthly Review Press, New York 1996, s. 39.

6 Ibidem. 
dołącza do wspólnej sprawy, jaką jest budowanie szczęśliwej wspólnoty; otwartą przestrzeń pełną oddechu, swobody i pracy, wykonywanej chętnie i z entuzjazmem; wielkiego światła, które oświeca i prześwieca, oczyszczając jednostkę ze złogów prywatności; a na koniec - last but not least - dobry powrót do stanu natury, w którym istota ludzka żyje i pracuje za dnia, a nie $\mathrm{w}$ wiecznej nocy. $\mathrm{Z}$ kolei metafora lampki implikuje odwrotny ciąg asocjacji: sztuczność światła, które nie daje życia; rozproszenie, w którym jednostki odpadają od uniwersalnego centrum w „odśrodkowym wirze"; leniwe zapadanie się w siebie, w małe prywatne królestwa "pod skórą"; półmrok, w którym czai się brud. Jeśli filozofia, jak twierdzi Derrida, jest tylko „białą mitologią”, w której metafory odgrywają rolę podstawową i istotnie pociągają za sznurki pojęciowych rozumowań, to myśl Marksa jest takim właśnie wybielonym mitem: obraz uniwersalnego słońca, które prześwietla i oczyszcza, towarzyszy mu od początku do końca jako wyobrażenie organizujące wizję komunistycznego społeczeństwa ${ }^{7}$. A jeśli Plessner - a jak się za chwilę okaże, także Derrida - ma swój obraz wiodący, to jest nim raczej sztuczne światło prywatnej lampki: wybitnie nierousseańskie wyobrażenie życia zdenaturalizowanego, które kultywuje swoją wewnętrzność (Innerlichkeit) jako cieniste królestwo sekretu.

W czwartym rozdziale książki, „Das Kampf ums wahre Gesicht. Das Risiko der Lächerlichkeit", Plessner opisuje to cieniste królestwo sekretu jako udzielną dziedzinę indywidualnej duszy, którą nazywa, w pełni świadom teologicznych konotacji tego pojęcia, ego absconditus, „Ja ukrytym". To ukryte, a zarazem ukrywające się serce jaźni to istota bez właściwości - jak u Roberta Musila, ohne Eigenschaften - rozdzierana sprzecznymi, niejasnymi impulsami, których rozwiązania dostarcza tylko wewnętrzna praca indywiduacji. Dusza, die Seele, jest więc tym prawdziwie niepodzielnym, a zarazem nieudzielalnym - in-dividuum czymś, co już Schelling nazywa „niepodzielną resztką" jako synonimem Selbstheit, jaźniowości: resztka, której nie może prześwietlić żadne pojęcie i żadna definicja; grudka, której nie może wyczyścić żaden wszystko uspójniający system. Nawet jeśli ta sekretna niepodzielność opiera się na braku, który postuluje w swoim rozumieniu człowieka prekursor Plessnera, Herder, to nie jest to luka w sensie negatywnym. To raczej brak dynamiczny, który przenicowuje tożsamość jednostki, relatywizując jej "społeczne aktualizacje” i sprawiając, że może się ona wycofać $\mathrm{z}$ nich wszystkich, by móc stać się kimś innym. Ten brak zatem to limes, granica, którą napotyka pełne uspołecznienie. Pozostając zawsze tylko wewnętrzna i wycofana, wybrakowana resztka opiera się wszelkiemu orzekaniu:

7 Por. J. Derrida, La mythologie blanche (la métaphore dans le texte philosophique), Relié, Paris 1971. 
Tym, co człowieka indywidualizuje, czyniąc go wewnętrznie niepodzielnym i pojedynczym, jest świadomość posiadania duszy, czyli życia w centrum jego wewnętrzności: wewnętrzności, które odczuwa, pragnie, myśli, i w swej głębi nie da się z niczym zewnętrznym porównać8.

Tyle, że to niepodzielne i nieporównywalne centrum nie spoczywa $\mathrm{w}$ sobie jak w bezpiecznym schowku; jest raczej pełne niepokoju (Unruhe), ponieważ pragnie się także uzewnętrznić - pokazać "prawdziwą twarz", a jednocześnie zostać jako takie uznanym, uniknąć „śmieszności". To uzewnętrznienie musi być jednak ruchem dialektycznym, w którym nie dojdzie do świetlnej anihilacji tego, co wewnętrzne; jeśli Entäusserung ma coś wyrażać, to tylko jako jednoczesne zniesienie i zachowanie cienia, w którym kryje się ego absconditus. Plessner pisze:

Podwójna natura życia psychicznego jednocześnie przyciąga je do ustalenia trwałej tożsamości (Fixierung) i od niego odciąga. Chcemy sami siebie zobaczyć i być widziani takimi, jakimi jesteśmy, ale także równie mocno chcemy się ukryć i pozostać nieznani, ponieważ pod każdym dookreśleniem naszego bytu kryją się niewypowiadalne możliwości bytu zupełnie innego (Anderssein) (ibidem, s. 63).

Kantowska "towarzyska nietowarzyskość" zatem to aporia, od której rozpoczyna się dialektyczny proces indywidacji, a pojedyncze Ja to wychyla się ku rozpoznaniu i uznaniu (moment heglowski), to skrywa się z powrotem, by testować nowe możliwości zaistnienia (moment schellingiański). Jak mawia D. W. Winnicott, psychoanalityk doskonale przystający do post-romantycznej antropologii Plessnera "to wielka radość się ukryć - ale i wielka rozpacz nie zostać znalezionym"”. Obaj, Plessner i Winnicott, sugerują, że dobra wspólnota to taka, która ten rodzaj gry umożliwia, pozwalając i na moment znalezienia/uznania i na moment ukrycia/zawieszenia uczestnictwa. Dobra - ograniczona wspólnota zakłada więc grę z cieniem, z tysiącami małych prywatnych lampek, których nigdy nie zaleje światło „uniwersalnego słońca”.

Nieograniczona radykalna communitas jest bowiem jak apokaliptyczny błysk i ogień, w którym ginie cieniolubna wewnętrzność. Jest jak,

8 H. Plessner, Grenzen der Gemeinschaft. Eine Kritik des sozialen Radikalismus, Suhrkamp, Frankfurt am Main 2002, ss. 61-62. I tak jak dla Plessnera radykalna wewnętrzność jest in-dividuum, tak dla Derridy sekret stanowi ab-solutum pojedynczości: „Sekretu nie może naruszyć żaden konsens, żadna publiczna przejrzystość. Jeśli mam się czymś dzielić, coś komunikować, obiektywizować czy tematyzować, to tylko pod warunkiem, że istnieje coś nieudzielalnego, niekomunikowalnego, nietematyzowalnego. A tym czymś jest absolutny sekret: ab-solutum w etymologicznym sensie tego terminu, czyli coś, co jest odłączone od wszelkiej więzi, odcięte i odseparowane" (TfS, 57).

9 D. W. Winnicott, Playing and Reality, Basic Books, London, s. 32. 
słowami Hegla, „furia zanikania”, w której zaciera się każdy indywidualny kontur: destrukcyjna, nie do życia, anihilująca ${ }^{10}$. Dobra wspólnota natomiast, choć równie radykalna $\mathrm{w}$ swoich egalitarnych ideałach, jest chłodniejsza: nie stawia na miłość, która wszystko spaja i łączy, aż do utraty pojedynczości, lecz - jak głosi motto odwołujące się do słynnego proroctwa Joachima z Fiore - na przyjaźń, która pozwala tak na osobność, jak na relację; więcej jeszcze, czyni osobność koniecznym warunkiem wszelkiej relacji. Podczas gdy w radykalnej communitas prześwietlonej „uniwersalnym słońcem” relacja zanika na rzecz klaustrofobicznej jedni, intensywnego bycia-razem, w którym wspólnota staje się jednym organem, "ręką milionopalcą" - w tej dobrej communitas bycie-razem przybiera łagodniejszą postać bycia-obok, gdzie miejscownik obok wyznacza inny model współistnienia: horyzontalny, niehierarchiczny, egalitarny, a jednocześnie wyzuty z przymusu absolutnego uczestnictwa. Podczas gdy, jak pisze Bernard z Clairvoix w swoim komentarzu do Pieśni nad pieśniami, miłość nie zna granic i przekracza wszystkie bariery w ekstatycznym porywie ${ }^{11}$ - przyjaźń nie tylko zna granice, lecz także je kultywuje. Jak z kolei pisze wielki teoretyk i adwokat przyjaźni Derrida, przyjaciel to nie kochanek, z którym pragniemy zlać się w mistycznej unii: przyjaciel to także "obcy", czyli hebrajski ger, którego przykazanie każe nam szanować i uznawać jako obcego właśnie, bez naruszenia granic jego „sekretu"12. Podczas więc gdy miłość obiecuje wypełnienie braku - jedność, pełnię, nienaruszalną całość „nieposzkodowanego życia” - przyjaźń pozostaje w kondycji wybrakowania. I podczas gdy miłość wiedzie do wspólnoty ciasnej niczym Pawłowe ,jedno ciało" - duch przyjaźni daje asocjację bardziej swobodną: bardziej towarzystwo właśnie niż spójną communitas.

Człowiek ma zatem pragnienie wspólnoty: nie jest, jak szydził sobie z klasycznych liberałów i ich "fałszywej antropologii” Marx, Robinsonem Crusoe, któremu do życia wystarczy towarzystwo księgi rachunkowej i posługacza Piętaszka; nie jest osobną wyspa, spokojną w swej splendid isolation. Tyle, że ta dobra wspólnota, odradzająca się jako wizja polityczna w każdej epoce - a zwłaszcza w nowożytności,

10 G. W. F. Hegel, Fenomenologia ducha, t. 2, przeł. A. Landman, PWN, Warszawa 1963, s. 187. W ten sposób Hegel opisuje rewolucję francuską.

11 „Jakże miłość jest gwałtowna i wszechpochłaniająca! Myśli tylko o sobie, niczym innym się nie interesuje, wszystkim pogardza, zadowala się tylko samą sobą! Myli porządki, statusy, hierarchie, nie dba o maniery, nie zna żadnych granic. Własność, różnice społeczne, rozsądek, przyzwoitość, ogłada i osąd muszą jej ulec i stać się wobec niej bezwolne": Bernard of Clairvaux, Sermon on the Song of Songs, 79:1, w: K. Walsh, O.C.S.O., The Works of Bernard of Clairvaux, vol. 2, Song of Songs I, Kalamazoo Publications Inc., Kalamazoo, MI 1981, s. 345.

12 Por. J. Derrida, The Politics of Friendship, przeł. G. Collins, Verso, London 1997, s. 105. 
w której co i rusz pojawia się pod postacią joachimicko-franciszkańskiego proroctwa trzeciego „wieku przyjaciół” - nie spala i nie zawłaszcza. W ramach pragnienia wspólnoty pojawia się jednak równie często silna pokusa „spalenia słońcem”, będąca jednocześnie pokusą wypełnienia braku: porzucenia wszelkiej jednostkowej „odporności”| immunitas na rzecz bezkompromisowego „udzielenia”/ communitas, w którym ginie trudny dialektyczny ruch odsłaniania się i chowania, zewnętrzności i wewnętrzności, opisany przez Plessnera i Winnicotta. Tak jakbyśmy byli nie tylko ćmami, które ciągną do małych lampek prywatności, by tam osmalić sobie skrzydełka (czyli, jak sugeruje Marks, stracić skrzydła i dać się pochłonąć tępej partykularności własnego ciała) - ale też Ikarami, których w niewytłumaczony sposób pociąga śmierć w żarze „uniwersalnego słońca” ${ }^{13}$. Ludzkość marzy więc o radykalnej nieograniczonej communitas od zawsze, choć ta jest dla jednostki śmiertelnym ryzykiem. Jednocześnie jednak marzy też o chwilach, w których aporia światło-cienia, bytu wspólnotowego i indywidualnej prywatności, znajduje swoje uspokojenie i pojednanie: nie za cenę utraty tej ostatniej, lecz przeciwnie, w imię jej asercji. W nowoczesności oba ideały wspólnoty radykalnej - Bataille'wskiej miłosnej ekstazy powszechnego ujawnienia i Joachimickiej, bardziej dyskretnej, „ery przyjaciół” - pojawiają się równie często jako dwa konkurencyjne modele wspólnotowego spełnienia. Obie wydają się stanowić, jak to ujął Ernst Bloch, „fantazję obiektywną", czyli tak powszechna, że nie sposób tu mówić o subiektywnej przypadkowości ${ }^{14}$. O ile jednak idea gorącej communitas opartej na zasadzie pełnego uczestnictwa wyłania się głównie w nowożytnej myśli politycznej, gdzie wspólnota jednoczy się pod egidą wspólnej sprawy - o tyle wizja chłodniejszego stowarzyszenia przyjaciół, w której odbywa się subtelna gra z cieniem, to zwłaszcza domena sztuki. Ta pierwsza istotnie staje się nade wszystko idea, czyli pojęciem - ta druga natomiast pozostaje głównie wizja, czyli wyobrażeniem. A jednak to ta druga właśnie, wyobrażona i wizyjna, okazuje się koniec końców trzeźwiejsza: nie wypełnia fantazmatycznie istotowego braku ludzkiego ideą wspólnej sprawy,

13 Ten samobójczo-ekstatyczny aspekt communitas jako słonecznego samospalenia jednostki pojawia się ze szczególną fantazmatyczną mocą u George Bataille'a, zwłaszcza w książce pt. Część przeklęta oraz Ekonomia na miarę wszechświata. Granica użytecznego, przeł. K. Jarosz, KR, Warszawa 2002, a później, z równie fantazmatycznym uporem, w twórczości Roberta Esposito, który uważa się za kontynuatora myśli Bataille'a: R. Esposito, Communitas: The Origin and Destiny of Community, trans. T. Campbell, Stanford University Press, Stanford 2009. Przeciwstawienie odporności/ / immunitas udzieleniu/ communitas pochodzi właśnie od Esposito.

14 Por. E. Bloch, The Spirit of Utopia, przeł. A. Nassar, Stanford University Press, Stanford 2000, s. 227. 
narodu, czy innego „wzniosłego obiektu ideologii”15, lecz ukazuje luźne stowarzyszenie istot nie do końca towarzyskich jako cel sam w sobie.

\section{"Dobra ogólność wszystkiego, co żyje"}

„Obiektywna fantazja” Ernsta Blocha to właśnie obrazy communitas, jakie od tysiącleci tworzy i przechowuje mesjańskie archiwum radykalnej nadziei. Bloch jest $\mathrm{w}$ istocie myślicielem tylko jednej idei albo - by trzymać się Derridiańskiego konceptu „białej mitologii”, który nam tu przyświeca - jednego wyobrażenia: od Ducha utopii, który ogłasza w roku 1918, przez Zasadę nadziei tworzoną w latach wojny na amerykańskim wygnaniu, aż po pisaną w latach sześćdziesiątych rozprawę o Arystotelesowskiej lewicy, jego imaginację zaprząta tylko owa szczególna obiektywna fantazja, w której uczestniczy nie tylko człowiek, lecz w ogóle cały materialny kosmos: „materia bowiem - pisze w eseju o Awicennie - także ma swoją własną wersję utopii i pragnie zrealizować ukryte w sobie możliwości"16. Tworząc religijne wyobrażenia - raju, mesjańskiego pokoju, złotego wieku - ludzkość, sama będąc częścią materialnego świata, pozwala materii na wydobycie jej „latentnej tendencji”, która, jak dotąd, realizuje się jedynie $\mathrm{w}$ fantazji, a jeszcze nie (noch nicht) w rzeczywistości. Tę obiektywną fantazję, zakorzenioną w samym Realnym, wyraża cała paleta obrazów, które niezmiennie łączy jeden motyw: czy będzie to rajski ogród, czy złoty wiek, przedstawiać on będzie stan pojednania, w którym wszystkie stworzenia duże i małe żyją obok siebie, sponte sua et sine lege, spontanicznie, błogo i nieobciążone jarzmem prawa; wszystkie korzystają wedle swych potrzeb z bogatych zasobów natury i rozkoszują się anomijną „powszechną rozwiązłością”, wchodzących ze sobą $\mathrm{w}$ dowolne konfiguracje i powinowactwa z wyboru. Od Biblii, przez Owidiusza, po Goethego i Bachofena, aż po dzisiejsze fantazje Derridy i Agambena - przewija się ten sam motyw: dobrej communitas wszystkich istot żyjących obok siebie w pokojowym "duchu przyjaźni” - bez wojny i przemocy, bez hierarchii i walki o uznanie, absolutnie egalitarnie i horyzontalnie. Czy będzie to Bachofenowska kraina Mutterrecht, gdzie życie upływa na przyjemności, zaklęte w łonie przyjaznej natury; czy będzie to alchemiczna utopia Wahlverwandschaften, którą Goethe opiera na Spinozjańskiej idei „przyjaźni stowarzyszającej”; czy będzie to

15 Por. S. Żiżek, Wzniosty obiekt ideologii, przeł. J. Bator, P. Dybel, Wydawnictwo Uniwersytetu Wrocławskiego, Wrocław 2001. W Lacanowskim ujęciu Żiżka, wzniosły obiekt jest tym, co wypełnia brak konstytutywny dla ludzkiej podmiotowości.

16 "Auch die Materie hat ihre Utopie; in der objektiv-realen Möglichkeit hört diese auf, eine abstrakte zu Sein": E. Bloch, Avicenna und die Aristotelische Linke, Rütten und Loening, Frankfurt am Main 1952, s. 75. 
Agambenowska „wspólnota, która nadchodzi”, gdzie quodlibeta - byty dowolne, puszczone wolno, wręcz byle jakie - żyją we wzajemnym pobliżu, nigdy nie wchodząc w kolizje ${ }^{17}$; czy wreszcie będzie to Derridiańska voyucracy, osobliwa formuła republiki wywodząca się z półświatka tajnych bractw ${ }^{18}$ - we wszystkich tych wizjach dochodzi do głosu duch przyjaznej tolerancji, która nie narzuca nikomu i niczemu żadnej odgórnej harmonii, lecz pozwala na, mówiąc słowami Adorno, „dobrą ogólność wszystkiego, co żyje"19.

Ta dobra ogólność nie realizuje mocnej formuły uwspólnotowienia $\mathrm{w}$ "duchu miłości” - miłości, która wszystko spaja, a tym samym uspójnia - lecz zdaje się na spontaniczną autopoiesis społecznego porządku, gdzie każdy nowy element dołączany jest indukcyjnie, ,jeden po drugim", bez apriorycznego dedukcyjnego planu. Tę aleatoryczność przyjaznego ładu widać doskonale na obrazach Cranacha Starszego: tak Złoty wiek, jak Raj, robią wrażenie kadru wyjętego z nieskończenie długiego, poziomego fryzu, do którego stworzenia dołączają kolejno i swobodnie, bez podawania racji i kryterium przynależności. Podczas gdy tradycyjny Wielki Łańcuch Bytów zorganizowany jest wedle ścisłej hierarchii i sztywno określonych różnic, ogród rajski mieści wszystkie istoty bez względu na to, czym są - choć jednocześnie nie nakazuje odróżnicowania. „Dobra ogólność” bowiem nie zawłaszcza i nie wywłaszcza jednostkowego bytu z jego sekretu - nieredukowalnej pojedynczości istnienia - i sprawia, że wszystkie byty dzielą ze sobą tylko to właśnie, co nieudzielalne: to, że zaistniały, każdy oddzielnie, osobno, , ,jeden po drugim", nie pod i nie nad w przedustawnej hierarchii istnień, lecz obok. Ani zatem sztywna hierarchia Tomaszowego świata zbudowanego na nexus amoris, ani gwałtowne odróżnicowanie gorącej wspólnoty: fantazja przyjaznej „dobrej ogólności wszystkiego, co żyje” zachowuje różni$c e$, jednocześnie nie organizując ich $w$ pionową strukturę. Poluzowuje więzy/więzi, proponując w zamian swobodne stowarzyszenie.

Teologicznie rzecz biorąc, pierwsza taka parada stworzeń pojawia się w Księdze Hioba, kiedy to Bóg ukazuje Hiobowi potęgę i rozmach swej kreacji; to jednak, co przez Boga zamyślone zostało jako pokaz siły i niemal przemarsz wojsk - od Behemota po Lewiatana - zamienia się w pochód istot, które zadziwiają samego Stwórcę, czującego, że w momencie stworzenia utracił on pełnię kontroli nad światem. $W$ rezultacie

17 Por. G. Agamben, Wspólnota, która nadchodzi, przeł. S. Królak, Sic!, Warszawa 2008.

18 Por. J. Derrida, Rogues. Two Essays on Reason, trans. P.-A. Brault, Stanford University Press, Stanford 2005 (voucracy wywodzi się od tytułu oryginalnego, czyli Voyous).

19 T. W. Adorno, O literaturze. Wybór esejów, przeł. A. Wołkowicz, Czytelnik, Warszawa 2005, s. 61. 
ten horyzontalny pochód istot, które dołączają się doń „jedno po drugim", nabiera charakteru wyzwania: patrz, oto my, Twoje dzieło, które zerwało się z łańcucha i istnieje teraz tak samo jak Ty. W ten sposób tworzy się pierwsze przymierze stworzeń, które konfrontuje się z Bogiem jako Stwórcą w duchu radykalnej univocatio entis, zanim jeszcze Duns Szkot wypowie tę zasadę explicite.

Fantazja radykalnego przymierza stworzeń znalazła szczególnie mocny, wzorcowy wyraz w słynnym obrazie Hieronima Boscha, czyli Ogrodzie ziemskich rozkoszy, umieszczonym w środkowej części tryptyku. Podczas gdy lewa strona obrazująca Raj sugeruje plan wertykalny, pnący się ku świetlistym niebiosom, prawa zaś przedstawiająca Piekło plan opadania w mroczną otchłań, ogród rozkoszy ziemskich rozpisany jest na planie poziomym, horyzontalnym, jakby bez nieba i bez piekielnych podziemi: bez słońca, ale i bez ciemności. Ludzie i nie-ludzie świętują tu czystą radość swojego cielesnego współistnienia: wolni od społecznych ról i hierarchii oddają się rozkoszy w duchu powszechnej przyjaźni; pokazują się sobie poza wszelkim sądem i oceną; po prostu tylko są. Dni Ostatnie Trzeciego Millenium upływają w delikatnym półmroku, ni to zmierzchu, ni świtu - w łagodnej wieczornej aurze: dokładnie więc takiej, w której, słowami Marksa, „zachodzi uniwersalne słońce”, tworząc przestrzeń już swobody i przyzwolenia - a jeszcze nie perwersji i występku ${ }^{20}$. Przestrzeń między „uniwersalnym słońcem”, które odziera wszystko, co żyje z sekretu - a "małą lampką prywatności”, w której (zdaniem Marksa przynajmniej) sekret musi zamienić się w zbrodnię.

Jaki jest jednak status tej fantazji? Czy można uczynić z niej projekt polityczny - czy też pozostawić jako fantazję właśnie? Istotą tej arcy-fantazji jest to, że reprezentuje ona czystą możliwość - das Real-Mögliche która zawsze musi przeciwstawiać się rzeczywistości we wszystkich jej odsłonach i aktualizacjach. Ernst Bloch także myśli o człowieku jako homo absconditus (niezależnie od Plessnera Bloch podejmuje teologiczny wątek z pism Marcina Lutra, gdzie „człowiek ukryty” to ta część duszy, która sekretnie komunikuje się z deus absconditus ${ }^{21}$ ), przyjmując prymat potencjalności nad aktualnością. To, co dla Herdera było tylko wybrakowaniem istoty ludzkiej niezdolnej do przeżycia w świecie natury, tu staje się pozytywnym brakiem aktualizacji, brzemiennej $\mathrm{w}$ "to, co realnie-możliwe" i co staje się podstawą dla "obiektywnej fantazji". Próba bezpośredniej realizacji ogrodu rozkoszy ziemskich jako modelu aktu-

20 Za chwilę zobaczymy, że w ten właśnie sposób - czyli jako strefę pomiędzy swobodą a występnością - Derrida zdefiniuje swoją voyoucracy, czyli „demokrację przyszłości".

21 Por. na ten temat: T. Ebke, Homo Absconditus. Das Motiv der unergründlichen Person in den Schriften von Friedrich Heinrich Jacobi, Emmanuel Levinas und Helmuth Plessner, Grin Verlag, München 2013. 
alnej communitas odebrałaby jej status tego, co realnie-możliwe - a o to wszak chodzi, by stała ona na straży transcendentalnego warunku możliwości możliwości. Rolą fantazji mesjańskiej nie jest więc dostarczać gotowego modelu do aktualizacji, lecz czynić możliwe możliwym: pozwolić na to, by kategoria radykalnych możliwości wdarła się w nasz przytłoczony zasadą rzeczywistości sposób myślenia i przewietrzyła go powiewem metafizycznej nadziei. Innymi słowy: rola mesjańskiej fantazji polega na byciu fantazją - lecz nie w lekceważącym sensie czegoś śmiesznie nierealnego, co natychmiast trzeba w bajki włożyć. Fantazja ma swą własną funkcję mobilizacyjna, in-spirująca duchem nadziei, której nie dają spełnione systemy utopijne, zbyt silnie przykute do „ontologii bytu społecznego" albo, jak to określa Derrida, "sspołecznej physis" ${ }^{22}$. Rolę tę świetnie opisuje Hans Blumenberg w eseju w poświęconym pojęciu nowoczesnej utopii:

Utopia, jak sama nazwa wskazuje, nie posiada swojego miejsca. Nie można wyrysować jej topografii tak, jak uczynił to Platon w metaforze jaskini, skąd przebiega jasna ścieżka ku oczywistej wyższej sferze idei. Utopia odgrywa inną rolę: jest krytyczna wobec tego, co już zaistniało. Nie mówi, czym należałoby tę rzeczywistość zastąpić. Mobilizuje on możliwość przeciw realności - już choćby po to, by tej drugiej nadać wyrazistszy kontur ${ }^{23}$.

Dzięki fantazji zatem możemy spojrzeć na nasz świat z zewnętrznej utopijnej perspektywy czystych możliwości i ujrzeć go w nowym krytycznym świetle. Co natychmiast uderza $w$ cytacie $z$ Blumenberga, to potajemne podstawienie, które zresztą nieustannie zachodzi też u Blocha: tam, gdzie język otwarcie religijny ulokowałby boską transcendencję jako to, co pozaświatowe, ci dwaj myśliciele umieszczają utopię, tyle że innego, nie-Platońskiego rodzaju. Nie tę, którą da się wyabstrahować czy wydedukować z jakiejkolwiek istniejącej topografii - lecz tę, która naprawdę nigdzie nie ma miejsca i jako taka pozostaje radykalnie odmienna od wszystkiego, co istnieje i co istnienie funduje. A to właśnie sama istota tego, co Derrida określa mianem mesjańskości.

22 Por. J. Derrida, Marx \& Sons, in: Ghostly Demarcations. A Symposium on Jacques Derrida's 'Specters of Marx, ed. M. Sprinker, Verso, London 1999, s. 257.

${ }_{23} \mathrm{H}$. Blumenberg, Wirklichkeitsbegriff und Staatstheorie, in: Schweizer Monatshefte: Zeitschrift für Politik, Wirtschaft, Kultur, Vol. 48 (1968-1969), nr 2, pp. 121-146, s. 126. 


\section{Użytek z nieporządku}

I tu właśnie wkracza Derrida - enter Derrida - ze swoją subtelną, dekonstrukcyjno-dialektyczną propozycją. Derrida, podobnie jak Plessner, jest wielkim zwolennikiem sekretności, czyli homo absconditus. W rozmowie z Maurizio Ferrarisem mówi wprost:

Mam upodobanie do sekretu, które w oczywisty sposób wiąże się z moim nie-przynależeniem; instynktownie rośnie we mnie lęk, wręcz paniczne przerażenie, kiedy tylko muszę stanąć w pełnym świetle - w przestrzeni politycznej, która nie pozwala na sekrety. Dla mnie ta nieszczęsna idea, że wszystko musi zostać wywleczone na publiczne języki bez uszanowania forum wewnętrznegości to jaskrawa oznaka totalitaryzacji systemu demokratycznego. Mogę to więc także sparafrazować w terminach etyki politycznej: tam, gdzie nie ma prawa do sekretu, wkracza totalitaryzm. Przynależność - sam fakt jej wyznawania, uwspólniania się bez reszty w języku, rodzinie, narodzie - oznacza koniec sekretu (TfS, 59; moja emfaza).

W wywiadzie tym, udzielonym już w późnej fazie twórczości, Derrida całkiem wyraźnie odcina się od pewnych tendencji roku 68, w którym uczestniczył na swój sposób - czyli pokrętnie i bez obozowej przynależności. Podobnie jak Plessner, którego chyba nigdy nie czytał, reaguje tu zwłaszcza krytycznie na rousseańskie fantazmaty demokracji bezpośredniej, spontanicznej i wspólnotowo zawłaszczającej. Z drugiej strony jednak, inaczej niż Plessner, Derrida nie jest gotów zrezygnować z wyobrażenia prawdziwie przyjaznej communitas, która jest dlań wiecznie żywą obiektywną fantazją szczególnego stanu społecznego, gdzie zostają zniesione role i hierarchie, a radosną świąteczną spójność zapewnia jedynie „polityka przyjaźni”. Późne pisma Derridy obfitują w odniesienia do communitas, która staje się $\mathrm{w}$ nich wręcz asymptotą demokratycznej wspólnoty: granica, do której przyszła demokracja - „demokracja, która nadchodzi" - ma dążyć, jednocześnie nigdy jej nie osiągając. Podczas bowiem gdy społeczeństwo potrzebuje praw i instytucji - zobiektywizowanych różnic, które je utrwalają - nawet najlepsza wspólnota rodem $\mathrm{z}$ "obiektywnej fantazji” zasadza się na anarchicznej i antynomicznej spontaniczności. Jednocześnie jednak fantazja ta zawiera „,skarb”, którego myśl polityczna nie może zatracić. O jaki więc skarb tu chodzi? I jak połączyć ze sobą z jednej strony, „upodobanie do sekretu” - z drugiej zaś pragnienie wspólnoty?

Kluczem do tej dialektycznej syntezy jest specyficzne rozumienie communitas jako stanu, w którym jednostka pokazuje się i jest widziana (by przypomnieć kategorie Plessnera), a jednocześnie nie ma ona nic do pokazania. Albo też właśnie odsłania ona - wystawia na pokazanie 
i uznanie - swoje wewnętrzne nic: nie to, czym jest i co określa jej byt w hierarchii społecznej (tożsamość, rola, prestiż), lecz brak, którym jest, kiedy wszystkie te orzeczenia ulegają zawieszeniu i kiedy wycofuje się ona do swego wewnętrznego nic, gdzie - zgodnie z naukami Herdera i Plessnera - jest tylko potencjalnościa, nigdy zaś aktualnością bytu. Jak mówi Derrida w tym samym wywiadzie: $w$ tak rozumianej wspólnocie...

...consensus nie znaczy porozumienia, pokoju czy porządku - consensus ten dotyczy niczego, czyli prostego faktu, że wszystko, co istnieje, podziela to, co niepodzielalne... to wspólnota tego, czego nie można uwspólnić; wspólnota, w której wspólnie wiemy, że (nie) mamy ze sobą nic wspólnego (ibidem, 58).

To oczywiście kolejna wariacja na temat tak zwanej „niewyznawalnej wspólnoty", nierzadka we francuskiej myśli społecznej, od Maurice Blanchota po Jean-Luc Nancy'ego ${ }^{24}$, do której Derrida dołącza swoje własne niewyznawalne, niedziałające i nieudzielalne nic wewnętrznego sekretu: herderowski brak, który nie domaga się dopełnienia i kompensacji. Jest jednak w tym opisie coś więcej, co wykracza poza inoperatywizm w stylu Blanchota czy Nancy'ego: jest u Derridy obcy tamtym dwóm ton mesjański, którą ową rozproszoną communitas, gdzie wszyscy wszystkim pokazują że nie mają sobie nic do pokazania, lokuje $\mathrm{w}$ innym imaginarium.

Messianicité, termin będący neologizmem Derridy, nie odnosi się do żadnej konkretnej religii Abrahamicznej, a zarazem do wszystkich trzech - judaizmu, chrześcijaństwa i islamu - gdzie denotuje pewną szczególną formułę ducha: ducha, który jest nie z tego świata, a jednak na ten świat oddziałuje, właśnie dzięki in-spiracji. W idiomie Derridy ruach to jednocześnie duch radykalnej wspólnoty albo przymierza stworzeń oraz duch radykalnej sprawiedliwości, którą tylko takie równościowe przymierze mogłoby zrealizować. Nie jest to jednak wizja utopijna w platońskim sensie topograficznym, gdzie, parafrazując Norwida, „utopia to tu, tylko troszkę dalej", lecz mesjańska wizja zupełnej odmienności, która nie istnieje i nie zaistnieje, a mimo to pozostaje operatywna w naszych zmaganiach z rzeczywistością, nachodząc nas jako Blochowska "obiektywna fantazja" albo jako Derridiańskie widmo, spectre. Es spukt, "W naszych głowach straszy", mówi Marks za Maksem Stirnerem i wiedziony metaforą „uniwersalnego słońca”, które przepłasza wszystkie widma, próbuje stworzyć domkniętą ontologię bytu społecznego, gdzie liczy się tylko to, co jest. Derrida protestuje: przeciwny marksowskie$\mathrm{mu}$ „słonecznemu” egzorcyzmowi duchów, dokonuje rewindykacji tej

24 Pisał o tym wyczerpująco Michał Krzykawski w swojej świetnej książce, Inne i wspólne. Trzydzieści pięć lat francuskiej filozofii, PWN, Warszawa 2016. 
półmrocznej sfery, w której rozkwita widmowa wizja ogrodu ziemskich rozkoszy, broniąc jej jako operatywnej fantazji. Jej sposób oddziaływania to właśnie ciagłe nawiedzanie - w snach, marzeniach, rojeniach na jawie, w nie do końca spojęciowanych wyobrażeniach naszych „białych mitologii", czyli sztuki i filozofii - które nie należy do twardej ontologii, lecz raczej hantologie: ontologii nawiedzonej ${ }^{25}$.

Jak jednak uchwycić to fantastyczne nawiedzanie i uczynić zeń etyczno-polityczny użytek? Jak zaprząc widmo do pracy sprawiedliwości? Ażeby lepiej zrozumieć mesjańską dialektykę Derridy, warto odwołać się do jeszcze jednego myśliciela: Victora Turnera, któremu zawdzięczamy najgłębsze antropologiczne ujęcie zjawiska radykalnej communitas. Zdaniem Turnera communitas to karnawałowe święto równości, w którym zostają zniesione wszystkie hierarchie i które dlatego właśnie nie może okazać się trwałe: to jedynie chwilowe zaburzenie, które przynosi ulgę od nacisków bycia w societas, czyli społecznej strukturze zbudowanej na sztywnych identyfikacjach, rolach i różnicach. Communitas potrafi nadejść - niczym widmo - nagle i niespodziewanie, i równie niewytłumaczalnie - niczym widmo - wyparować. Wszelkie wysiłki, by widmo to złowić i oswoić - przedłużyć stan radosnego odróżnicowania tak, by stał się bezpośrednim wzorcem życia społecznego - kończą się fatalnie: egalitarny, z góry już „utracony skarb rewolucji” 26 odchodzi tak nagle, jak się pojawił, pozostawiając po sobie kolejną hierarchiczną formę societas, która na nowo wiąże uprzednio uwolnioną energię w Plessnerowską Fixierung, czyli stabilizującym u-staleniem i u-sztywnieniem ${ }^{27}$. W innym z kolei wariancie, który opisuje René Girard, przedłużające się święto anarchicznej przyjaźni kończy się gwałtownym kryzysem ofiarniczym: w zdehierarchizowanej społeczności narasta epidemia przemocy, której zapobiec może już tylko okrutny rytuał wyasygnowania i poświęcenia kozła ofiarnego - czyli tego, który w tym powszechnym odróżnicowaniu zachował resztkę różnicy i tym samym się „wychylił” (zgodnie z tragiczną zasadą apex, czyli wierzchołka ściągającego na siebie gniew bogów $)^{28}$. Świętowanie wspólnego braku, czyli tego nic, którym jest w swojej sekretnej głębi każda ludzka istota, jest więc aktem ryzykownym: w swojej odsłonie apokaliptycznej prowadzi wprost do Heglowskiej „furii zanikania".

25 Por. J. Derrida, Widma Marksa. Stan długu, praca żałoby i Nowa Międzynarodówka, przeł. T. Załuski, PWN, Warszawa 2016, s. 73.

26 Por. H. Arendt, O rewolucji, przeł. M. Godyń, Czytelnik, Warszawa 2003.

27 Por. zwłaszcza V. Turner, Gry społeczne, pola i metafory: symboliczne działanie w społeczeństwie, Wydawnictwo Uniwersytetu Jagiellońskiego, Kraków 2005.

28 Por. zwłaszcza R. Girard, Sacrum i przemoc, przeł. M. Plecińska, Brama, Poznań 1993. 
A jednak, pomimo całej swej niepochwytnej zwiewności i apokaliptycznego ryzyka, communitas naprawdę jest skarbem: w żadnym innym stanie naszego bytu wspólnotowego nie odczuwamy solidarności z innymi istotami w tak radosny i wyzwalający sposób. Dlatego też mesjańska dialektyka Derridy zmierza do istotnej modyfikacji teorii Turnera, gdzie societas i communitas krążą w niezmiennym cyklu naprzemiennych karnawałów i usztywnień, rewolucji i restauracji, kryzysów i stabilizacji: w ujęciu Derridy widmowy błysk communitas nie musi już służyć zasadzie back to order, czyli "odtworzeniu ładu”, tak jak we wszystkich tradycyjnych ujęciach karnawału, od Bachtina począwszy. Nie w tym rzecz jednak, by communitas ustabilizować, ustalić i utrwalić, i zastąpić nią organizację societas: tego rodzaju normalizacja oznaczałaby po prostu porzucenie radykalnej wspólnoty na rzecz społecznego ładu, czyli rezultat dokładnie odwrotny do zamierzonego. Celem fantazji communitas nie jest pełna aktualizacja, lecz, zgodnie z Blochem, uczynienie możliwego możliwym - czyli nieustanna subwersja praw i instytucji societas, podmywająca je od spodu podziemnym prądem, czyniąca ich fixus bardziej na obraz i podobieństwo fluxus, rozmywająca granicę między płynnym flux wspólnoty a stabilnym Fixierung hierarchicznego społeczeństwa, albo - jakby powiedział Turner, inspirowany hippiesowskimi ruchami roku 68 - wpuszczająca nieco giętkiego flow w usztywniony square mieszczańskiego trybu życia. Jeśli więc Hegel definiuje pracę jako „odwleczoną destrukcję"29, to na tym też polega dialektyczny pomysł Derridy, aby widmo communitas zaprząc do pracy na rzecz ideału sprawiedliwości. Ogień, który grozi całopaleniem, jeśli uwolnić go bez żadnych bezpieczników, może stać się źródłem energii, jeśli go okiełznać: "odwleczenie destrukcji” staje się wówczas pracą jako transformacja społecznej rzeczywistości. Czymś w rodzaju systematycznego podniszczania "wszystkiego, co stałe i stanowe" (alles Stehende und Ständische z Manifestu komunistycznego Marksa) w celu odsłonięcia bardziej giętkiej i plastycznej natury ludzkich praw i instytucji, zakorzenionych nie $\mathrm{w}$ odwiecznym i niezmiennym lex naturalis, lecz w płynnej dynamice stanowionych konwencji.

Dla Turnera zresztą to dialektyczny ruch charakterystyczny dla całej nowożytności, wiedzionej Dantejskim ideałem vita nuova, czyli właśnie „nowego życia”: długotrwała praca na rzecz transformacji bytu społecznego, którego prawa i instytucje nie wzorują się już na odwiecznym prawie naturalnym, lecz przybierają formę coraz bardziej samoświadomej konwencji, uginając się pod wpływem rewolucyjnej fantazji powszechnej wolności, braterstwa i równości. Ze względu na tę law-bending, elastyczną tendencję do uginania prawa, do czynienia go bardziej giętkim i podatnym na zew radykalnej sprawiedliwości, Turner nazywa nowo-

${ }^{29}$ G. W. F. Hegel, Fenomenologia ducha, t. 1, s. 221. 
czesność epoką liminoidalną: trwale i na zawsze już umiejscowioną na progu między sztywnym nomos a anarchią i anomia, hierarchią a karnawałem, societas a communitas ${ }^{30}$. Tu zresztą Marks by się zgodził: definicja nowożytności jako czasu, w którym „wszystko, co stałe - feudalne, stanowe, zakrzepłe - wyparowuje", doskonale pokrywa się z ideą epoki liminoidalnej. Nie inaczej Plessner: jego wizja człowieka jako istoty pozytywnie wybrakowanej zawiera w sobie Turnerowski obraz liminoidalności jako dynamicznego bycia zawsze na progu między potencjalnością a konkretną społeczną aktualizacją.

To także, zdaniem Derridy, obietnica przez nowoczesność złożona: nie tyle pełna realizacja communitas jako societas - co, jak już wiemy, jest nie tylko logicznie niemożliwe, ale i niepożądane - ile raczej ciągła nawiedzająca subwersja wszystkich społecznych praw uprawiana $\mathrm{w}$ duchu wspólnoty radykalnej: zawsze tylko $w$ duchu, ponieważ to duchowe widmo nigdy nie może stać się dosłowną literą. Communitas nigdy więc nie stanie się modelem pozytywnej utopii: to raczej wieczna negatywność, Goetheański „duch, który zawsze mówi nie”, społeczny daimonion liminoidalnej subwersji. Za każdym razem jednak, kiedy tylko societas zaczyna prezentować się $\mathrm{w}$ terminach naturalnej hierarchii wspartej na bosko-naturalnym prawie - daimonion wspólnoty radykalnej podnosi głos protestu, w epoce nowoczesnej głośniej niż kiedykolwiek indziej. Nawet więc jeśli tej wiecznej negatywności nie da się przekuć na projekt pozytywny, to w żadnym sensie nie znaczy to, że można o niej zapomnieć albo całkiem ją zneutralizować. Przeciwnie: krytyczna grawitacja tego społecznego limes, jaki stanowi wspólnota radykalna, staje się natchnieniem - in-spiracja, w-duchowieniem - za sprawą którego prawa i instytucje zachodniej liberalnej społeczności trwale zmieniają swój kształt. Ta zmiana ma charakter ściśle dialektyczny: pod stałym naciskiem swojej antytezy, societas zachowuje - zapamiętuje, a zarazem uwewnętrznia (heglowskie Er-innerung) - moment communitas, jednocześnie znosząc go w jego bezpośredniości. Apokaliptyczny błysk radykalnej wspólnoty nie niszczy już i nie spala mieszczańskich instytucji, lecz płonie w nich samych jako wewnętrzna energia sterująca ich przemianą. Między zatem secret society bractw Wolnego Ducha, uprawiających swój wspólnotowy karnawał w podziemnych strukturach późnośredniowecznego mieszczaństwa, a zasadą równości wobec prawa wszystkich jednostek, uwewnętrznioną przez liberalną konstytucję, rozpina się kilka kluczowych stuleci, w których nowoczesna liminoidalność staje się powszechnym faktem: subwersją zdyscyplinowaną i wyzyskaną. To pierwszy taki

30 V. Turner, From Liminal to Liminoid, in Play, Flow, and Ritual: An Essay in Comparative Symbology, „Rice University Studies”, 60, nr 3 (1974), s. 69. 
eksperyment w dziejach: jakby powiedział Richard Sennett, pierwszy i wzorcowy pożytek z nieporządku, czyli use of disorder ${ }^{31}$.

\section{Mesjański liberalizm: prawo podszyłe bez-prawiem}

W istocie, gdyby chcieć podsumować polityczną wizję Derridy, w której prawo stanowione (nigdy naturalne, raczej droit niż loi) wciąż jest nawiedzane przez widmo radykalnej sprawiedliwości, to należałoby nazwać ją mesjańskim liberalizmem. Podczas gdy jego lewicowość przybiera postać spektralna, liberalizm Derridy stawia na transformację prawa: na to, by było ono coraz bardziej i coraz wyraziściej zgodne ze swą deklaracją $\mathrm{w}$ której samo to prawo określa się jako prawo każdej jednostki do życia, wolności i poszukiwania szczęścia. Lewicowy duch communitas nie może przestać straszyć/ nawiedzać liberalnej societas, ponieważ bez niego prawo liberalne traci sens: pozbawić go tej „obiektywnej fantazji” znaczyłoby wydrzeć mu jego żywe serce ${ }^{32}$.

Niewykluczone bowiem, że sama idea jednostki, dla której prawo to zostało stworzone, wywodzi się wprost z ulotnego doświadczenia radykalnej wspólnoty: owego widma, które u progu nowożytności nachodziło zachodnie społeczności częściej i intensywniej niż kiedykolwiek, wytwarzając całą paletę millenarystycznych oczekiwań. Wbrew ujęciu, jakie prezentują klasyczne teksty liberalnych ojców założycieli, od Locke'a do Jeffersona, jednostka nie jest w nim abstrakcyjnym "człowiekiem" zredukowanym do ogólnej ludzkiej natury, lecz żywą pojedynczością, chwilowo wyzutą ze swoich społecznych determinant w strumieniu - flow - kiedy to ulegają one czasowej liwidacji: jest żywym brakiem mającym nic do pokazania. Liberalna jednostka byłaby więc ra-

31 Por. R. Sennett, The Uses of Disorder: Personal Identity and City Life, W. W. Norton \& Company, New York 1992.

32 Relacja między (lewicowym) widmem a (liberalnym) bytem jest u Derridy tym samym, co relacja między sprawiedliwością a prawem. Por. kolejny fragment z wywiadu Ferrarisa: „W Widmach Marksa przypomniałem potężną sentencję Levinasa: 'relacja $z$ innym to sprawiedliwość'... Relacja $z$ innym nie wyczerpuje się w pojęciu prawa... Prawo (droit) posiada historię, która daje się zdekonstruować; jest restytucją redystrybucją, ekwiwalencją - podczas gdy sprawiedliwość wszystko to przekracza i przemieszcza. Sprawiedliwość jest - by wrócić do frazy Hamleta, która odgrywa ważną rolę w Widmach - zawsze 'wypadła z kolein', out of joint, aus den Fugen. W tym też leży sedno mojej debaty z Heideggerem, który w swoim wielkim tekście o Anaksymandrze umieszcza dike po stronie Fuge, czyli harmonii, zestrojenia, konjunkcji. Ja tymczasem odpowiadam, że tym, czego tu trzeba, jest dysjunkcja: roz-szczepienie, które może stać się złem, ale które mimo to pozostaje warunkiem sprawiedliwości. Dekonstrukcja jest sprawiedliwościa, czyli dysproporcją między mną a innym, także między mną a mną samym jako innym, mną z 'sekretem'”' (TfS, 556-557). 
czej Derridiańskim arrivant, który zawsze nadchodzi z przyszłej „ery przyjaciół", a jednocześnie revenant, który nachodzi społeczną teraźniejszość z tej odmiennej modalności, jaką stanowi ulotna communitas. Byłaby antynomiczną pojedynczością tej wiecznie nadchodzącej i nawiedzającej wspólnoty, którą Derrida określa jako „chora tego, co polityczne" ${ }^{\prime 3}$ - a nie hipostazą powszechnej ludzkiej natury. Tym, co prawo liberalne uchwytuje $z$ jednostki, nie jest bowiem jej abstrakcyjna natura, lecz ulotny/widmowy moment wspólnotowego flux, który zostaje zapamiętany i uwewnętrzniony w strukturze prawa - jako jego bez-prawna iskra, serce, sekretny płomień życia.

To również tłumaczy, dlaczego ta pamięć o communitas jako a-temporalnym - a w tym sensie także u-topijnym, nie dającym się topograficznie umiejscowić - zaburzeniu societas tak ściśle wiąże się u Derridy z jego medytacją nad śmiercia a ściślej: nad życiem, które doświadcza powszechnego zrównania wobec Śmierci. Jak już pokazał Johan Huizinga w Jesieni średniowiecza, millenarystyczny obraz danse macabre - mrocznej parady ofiar dżumy, prowadzonych, bez względu na ich społeczny status, w jednym szeregu przez roztańczony szkielet - to najpierwotniejszy wzorzec wspólnoty radykalnej, odróżnicowanej wobec śmierci, która bierze wszystkich na równi, i pana, i niewolnika. Zdaniem Huizingi to właśnie ta ciemna wspólnota w śmierci doprowadza do zachwiania, a następnie upadku feudalnego ładu, naocznie ukazując, że w oczach śmierci - a także i Boga, który daje śmierć - hierarchia jest tylko ludzką konwencja, w związku z czym natychmiast wyparowuje (jak pisze Marks: verdämpft $)^{34}$.

Ten ponury wątek zaczyna jednak nabierać weselszych barw już jedno stulecie później, kiedy to danse macabre przemienia się $\mathrm{w}$ parade miłości, która naśladuje demokratyczną formułę tańca śmierci, tym razem jednak celebrując życie i wolny eros. Ta przemiana nie jest zresztą kompletna. Jak z kolei dowodzi Denis de Rougemont w książce Miłość a świat kultury zachodniej, późnośredniowieczny Eros prowansalskich trubadurów jest tylko cienką maską pod którą nadal skrywa się Tanatos. W wolnej miłości łączącej duchem przyjaźni panów i sługi wyraża się nie egalitarny entuzjazm, lecz tylko poczucie anomii i entropii, które opanowuje zmierzchające zachodnie feudum; uczestnicy parad miłości to zatem ci sami morituri, idący-na-śmierć, co w starym Totentanzu, tyle

33 Derrida, Rogues, s. 44. Chora to platoński termin oznaczający "naczynie”, ale także „podłoże”, które „daje miejsce” wszystkiemu, co wyłania się, by zaistnieć. Chora jest więc "miejscem miejsc", a w tym sensie brakiem i nieobecnością która dopiero obecność umożliwia: jest czystą potencjalnością będącą warunkiem wszelkiej aktualizacji.

34 Por. J. Huizinga, Jesień średniowiecza, przeł. R. Stiller, vis-a-vis/ Etiuda, Kraków 2016, zwłaszcza rozdział „Wizja śmierci”. 
że zdeterminowani, by swoje Dni Ostatnie spędzić wśród niczym już nie krępowanej „powszechnej rozwiązłości” ${ }^{\prime 35}$.

W paradach budzi się więc pogański duch pogrzebowych orgii: niemal dosłownie, bo odbywają się one na cmentarzysku feudalnej hierarchii i Wielkiego Łańcucha Bytów, w którym wyrażał się metafizyczny ład katolickiego średniowiecza. Bezład i bez-prawie, które wymknęły się dyscyplinie karnawału, anomijnie rozkładają i rozwiązują stary porządek, na razie nic nie dając w zamian - oprócz chwilowej rozpusty w obliczu śmierci. Widać to bardzo wyraźnie na zasłużenie słynnym obrazie Sandro Botticellego pt. Primavera: parada miłości towarzysząca Wiośnie ma osobliwie trupi wygląd, który nadaje dziełu głęboko niesamowity, unheimlich, charakter. Nawet sama Wiosna przypomina zwłoki: woskowo blada, pozbawiona ekspresji, statyczna, nieżywa, jest jak transi, późnośredniowieczna figura w stanie dekompozycji, czyli w liminoidalnym „przejściu” między trupem a widmem.

Czy zatem Derridiańskie widmo to właśnie ta śmiertelna zjawa? Niekoniecznie. Wczesna nowożytność raz jeszcze wyciągnęła żywotne soki z gnijącej jesieni - Wiosna Botticellego jest, wbrew tytułowi, zdecydowanie jesienna, na co wskazuje choćby obecność Wiatru Północnego, który za chwilę uśmierci wiosenny powiew życia - i, czyniąc pozytywny "użytek z nieporządku”, przyjęła ten tanatyczny obraz dehierarchizacji za swoje motto, pozbawiając go jednak jego pierwotnego entropijnego smutku. Użyła lekcji wspólnoty radykalnej, by stworzyć nową koncepcję jednostki: swobodnej, dynamicznej, nieobciążonej społecznym statusem, gotowej piąć się w górę ludzkich hierarchii - tak jak wcześniej gotowa była runąć w dół, ku powszchnemu zatraceniu i śmierci. Użytek $\mathrm{z}$ nieporządku, ale także pozytywny użytek z braku definiującego ludzką istotę - oto lekcja, na jakiej oparła się Nowa Era, składając nam wszystkim obietnice przyjaznej wspólnoty, tego wielkiego niedokończonego projektu nowoczesności, w którym do dziś skrycie pracuje „obiektywna fantazja".

\section{Afirmacja braku}

Wizje, widma, wyobrażenia: czy z perspektywy solidnego filozofa polityki nie brzmi to cokolwiek niepoważnie? Taki właśnie ton wcale nie lekkiego zniecierpliwienia przybiera większość replik na Widma Marksa, które zarzucają Derridzie brak zakorzenienia w ontologii społecznej - do czego zresztą Derrida wprost się przyznaje ${ }^{36}$. Tak bowiem jak wspólnota

35 D. de Rougemont, Miłość a świat kultury zachodniej, PAX, Warszawa 1968, s. 58.

36 Por. znów Ghostly Demarcations, tom stanowiący listę zarzutów pod adresem Widm Marksa Derridy, w tym zwłaszcza szczególnie napastliwe wystąpienia Terry Eagletona oraz Antonio Negriego. 
zaprojektowana przez filozofów różni się od fantazji przymierza stworzeń, tak twarda utopia wyrastająca z topografii społecznej rzeczywistości różni się od mesjańskiego widma. Ulotny duch przyjaźni to bowiem typowy "kamień odrzucony", który nie nadaje się na solidny fundament utopii, na którym jednak Derrida, w powtórzonym geście mesjańskim, buduje swoje „podejrzane” tajne stowarzyszenie jako zaczyn przyszłego społeczeństwa sekretu.

Nie jest to jednak tylko gra, w której Derrida drażniłby się z poważnymi marksistami od wielkich utopii społecznych (choć i ten element pojawia się w jego ironicznej replice pt. „Marks \& Sons”). Interwencja Derridy polega na uświadomieniu nam, że niedokończony projekt nowoczesności możliwy jest tylko dzięki wielkiej antropologicznej transformacji, w której człowiek nowoczesnego Zachodu zmienia stosunek do kwestii swojego istotowego wybrakowania. Nie tylko nie dąży on już za wszelką cenę, by brak ten „,skompensować" i „zastępczo wypełnić", jak to rzecz ujmuje post-Herderowska linia antropologii filozoficznej (na Gehlenie i Lacanie kończąc), lecz zaczyna traktować go pozytywnie: jako przewagę skrytej potencjalności nad ujawnioną aktualnością (Plessner i Bloch), a także jako dobrą subwersję mesjańskiego widma wobec społecznego ładu (Derrida). Dialektyczny zamysł Derridy znajduje więc najlepszy wyraz w koncepcji contre-institution, czyli przeciw-instytucji: innej instytucjonalności, w której zostaje zachowany element krytyki instytucji jako takiej, czyli wszystkich tych czynników, które strukturują societas -

Tym, co pozostaje trwałe w moim myśleniu - mówi dalej w tym samym wywiadzie - jest krytyka instytucji, ale nie ta podejmowana z utopijnej perspektywy pre- albo nie-instytucjonalnej spontaniczności, lecz raczej taka, która wychodzi od idei przeciw-instytucji. Moim zdaniem nie istnieje nic poza instytucjami. Jestem więc zawsze rozdarty między krytyką instytucji a marzeniem o innej instytucji, która, w nieskończenie długim procesie, zastąpi instytucje opresyjne, przemocowe bądź w ogóle niedziałające. Idea przeciw-instytucji, nie mająca nic wspólnego z dzikościa, bezpośredniością czy spontanem - oto naczelny motyw mojej dekonstrukcji... Niegdyś zdefiniowałem Państwo - takim, jakie być powinno jako właśnie przeciw-instytucję, niezbędna, by stworzyć opozycję dla tych instytucji, które reprezentują interesy partykularne. To samo powiedziałbym o prawie międzynarodowym (TfS, 50-51).

Jest więc miejsce i na strukturę instytucjonalną i na prawo, pod warunkiem jednak, że zniesie ono w sobie - czyli zarazem odpomni i zachowa - uniwersalizujący moment autokrytyczny. W późnym eseju pt. Voyou (ten nieprzetłumaczalny tytuł można od biedy oddać terminem Delikwenci, gdzie "delikwent" to słowo sugerujące płynny żywioł rozpuszczenia i rozwiązłości, fluxu, a zarazem pewnego wybrakowania 
i skrytości, które unikają publicznego światła) Derrida puszcza wodze "obiektywnej fantazji” i kreśli obraz „nadchodzącej demokracji” jako voyoucracy:

Voyoucracy to korumpująca siła ulicy, nielegalna i pozaprawna, która w końcu przybiera formę rządów delikwenckich, jednocześnie zorganizowanych i tajnych. Staje się wirtualnym państwem tych wszystkich, którzy reprezentują zasadę nieporządku - zasadę nie anarchicznego chaosu, lecz nieporządku ustrukturowanego, spisku i konspiracji, planowanej subwersji wobec ładu publicznego... Voyoucracy jest więc zasadą nieporządku, a tym samym zagrożeniem dla ładu publicznego, lecz jako cracy reprezentuje już coś więcej niż tylko luźny zbiór pojedynczych „delikwentów". To zasada nieporządku jako porzadku zastępczego (trochę jak w tajnym stowarzyszeniu, sekcie albo bractwie wolnomularskim)... Voyoucracy stanowi i instytucjonalizuje pewien rodzaj przeciw-władzy oraz przeciw-obywatelstwa ${ }^{37}$.

Czy taka wizja odpowiadałaby Plessnerowi? Choć nie brakuje konserwatywnych interpretacji autora Granic wspólnoty ${ }^{38}$, to jednak wydaje się, że jego afirmacja ludzkiego braku jako źródła trwałej subwersji porządku społecznego mogłaby prowadzić wprost do Derridiańskiej wizji voyoucracy, czyli luźno-(roz)wiązłej "demokracji delikwentów”, która tę dialektykę wybrakowania i wypełnienia, sekretu i jawności, realizuje w sposób prawdziwie konsekwentny.

\section{Bibliografia}

Adorno T. W., O literaturze. Wybór esejów, przeł. A. Wołkowicz, Czytelnik, Warszawa 2005.

Agamben G., Wspólnota, która nadchodzi, przeł. S. Królak, Sic!, Warszawa 2008.

Arendt H., O rewolucji, przeł. M. Godyń, Czytelnik, Warszawa 2003.

Bataille G., Część przeklęta oraz Ekonomia na miarę wszechświata. Granica użytecznego, przeł. K. Jarosz, KR, Warszawa 2002.

Bloch E., Avicenna und die Aristotelische Linke, Rütten und Loening, Frankfurt am Main 1952.

Bloch E., The Spirit of Utopia, przel. A. Nassar, Stanford University Press, Stanford 2000.

Blumenberg H., Wirklichkeitsbegriff und Staatstheorie, „,Schweizer Monatshefte: Zeitschrift für Politik, Wirtschaft, Kultur", vol. 48 (1968-1969), nr 2, ss. 121-146.

37 J. Derrida, Rogues, op. cit., s. 65.

38 Por. zwłaszcza wstęp Zdzisława Krasnodębskiego do: H. Plessner, Pytanie o conditio humana. Wybór pism, przeł. M. Łukasiewicz, PIW, Warszawa 1988. 
Derrida J., La mythologie blanche (la métaphore dans le texte philosophique), Relié, Paris 1971.

Derrida J., The Politics of Friendship, przeł. G. Collins, Verso, London 1997.

Derrida J., Marx E Sons, in: Ghostly Demarcations. A Symposium on Jacques

Derrida's 'Specters of Marx,' ed. M. Sprinker, Verso, London 1999.

Derrida J., A Taste for the Secret, Polity Press, London 2001.

Derrida J, Rogues. Two Essays on Reason, trans. P.-A. Brault, Stanford University Press, Stanford 2005.

Derrida J., Sauf le nom, Gallilee, Paris 1995 / On the Name, przeł. J. P. Leavey, Stanford University Press, Stanford 2006.

Derrida J., The Beast and the Sovereign, vol. 1, przeł. G. Bennington, The University of Chicago Press, Chicago 2009.

Derrida J., Learning to Live Finally. The Last Interview, przeł. P.-A. Brault, Melville House, New York 2011.

Derrida J., Widma Marksa. Stan długu, praca żałoby i Nowa Międzynarodówka, przeł. T. Załuski, PWN, Warszawa 2016.

Ebke T., Homo Absconditus. Das Motiv der unergründlichen Person in den Schriften von Friedrich Heinrich Jacobi, Emmanuel Levinas und Helmuth Plessner, Grin Verlag, München 2013.

Esposito R., Communitas: The Origin and Destiny of Community, przeł. T. Campbell, Stanford University Press, Stanford 2009.

Fischer E., How to Read Karl Marx, przeł. A. Bostock, Monthly Review Press, New York 1996.

Girard R., Sacrum i przemoc, przeł. M. Plecińska, Brama, Poznań 1993.

Hegel G. W. F., Fenomenologia ducha, t. 2, przeł. A. Landman, PWN, Warszawa 1963.

Huizinga J., Jesień średniowiecza, przeł. R. Stiller, vis-a-vis/ Etiuda, Kraków 2016.

Krzykawski M., Inne i wspólne, Trzydzieści pięć lat francuskiej filozofii, PWN, Warszawa 2016.

Lacan J., Ecrits, Editions de Seuil, Paris 1966.

Plessner H., Pytanie o conditio humana. Wybór pism, przeł. M. Łukasiewicz, PIW, Warszawa 1988.

Plessner H., Grenzen der Gemeinschaft. Eine Kritik des sozialen Radikalismus, Suhrkamp, Frankfurt am Main 2002.

Rougemont D. de, Miłość a świat kultury zachodniej, PAX, Warszawa 1968.

Sennett R., The Uses of Disorder: Personal Identity and City Life, W.W. Norton \& Company, New York 1992.

Turner V., From Liminal to Liminoid, in Play, Flow, and Ritual: An Essay in Comparative Symbology, "Rice University Studies", vol. 60, 1974, nr 3.

Turner V., Gry społeczne, pola i metafory: symboliczne działanie w społeczeństwie, Wydawnictwo Uniwersytetu Jagiellońskiego, Kraków 2005.

Walsh K., The Works of Bernard of Clairvaux, Kalamazoo Publications Inc., Kalamazoo, MI 1981.

Winnicott D. W., Playing and Reality, Basic Books, London 1975. 
Żiżek S., Wzniosty obiekt ideologii, przeł. J. Bator, P. Dybel, Wydawnictwo Uniwersytetu Wrocławskiego, Wrocław 2001.

\section{Streszczenie}

\section{Granice wspólnoty, albo gra z cieniem: brak, sekret i duch przyjaźni w antropologii Plessnera i Derridy}

Esej przedstawia konfrontację między Helmuthem Plessnerem i Jacquesem Derridą jako dwoma kontynuatorami antropologii filozoficznej, dyscypliny stworzonej przez Johanna Gottfrieda Herdera, który w słynny sposób zdefiniował człowieka jako „niedoskonałą istotę" (Mängelwesen). Chociaż Derrida najprawdopodobniej nie był świadomy Plessnerowskiej interpretacji myśli Herdera, to powinowactwa pomiędzy tymi dwoma myślicielami są uderzające. $\mathrm{W}$ przeciwieństwie do konserwatywnego skrzydła Herderianistów, które podkreśla potrzebę zrekompensowania pierwotnego braku konstytutywnego dla człowieka (np. Arnold Gehlen), zarówno Plessner, jak i Derrida wykorzystują myśl, że brak może być wartością samą w sobie i że nie wymaga on natychmiastowej kompensacji kulturowej. W ich odczytaniu tradycji herderowskiej brak, który wymaga kompensacji, staje się „,sekretną" zasadą indywidualizacji i jako taki stanowi niezbędny fundament liberalnego społeczeństwa opartego na duchu przyjaźni, pozwalający na grę z cieniem indywidualnej prywatności. Argumentując przeciw utopii radykalnej wspólnoty, Plessner i Derrida przedstawiają zarys innego społeczeństwa respektującego granice i dystans implikowany przez konstytutywny brak, którego nigdy nie można w pełni ujawnić.

Słowa kluczowe: Herder, Plessner, Derrida, antropologia filozoficzna, wspólnota, społeczeństwo, brak, sekret, prywatność, przyjaźń

\section{Summary}

\section{The Limits of Community, or Playing with the Shadow: The Lack, the Secret, and the Spirit of Friendship in Plessner's and Derrida's Anthropology}

The essay stages a confrontation between Helmuth Plessner and Jacques Derrida as the two continuators of philosophical anthropology, the discipline created by Johann Gottfried Herder who famously defined man as a 'deficient being' (Mängelwesen). Although Derrida was most probably unaware of Plessner's interpretation of Herder's thought, the affinities between the two thinkers are striking. Unlike the conservative wing of the Herderians, which stresses the need to compensate the original constitutive lack of human being (e.g. Arnold Ge- 
hlen), both Plessner and Derrida toy with the idea that the lack can be of value itself and that it does not call for the immediate cultural compensation. In their reading of the Herderian tradition, the lack which resists compensatory filling becomes a "secret" principle of individuation and as such an indispensable foundation of liberal society, based on the spirit of friendship, which allows for the play with the shadow of individual privacy. Writing against the utopia of the radical community, Plessner and Derrida give an outline of another society respecting the limits and the distance implied by the constitutive lack which can never by fully revealed.

Keywords: Herder, Plessner, Derrida, philosophical anthropology, community, society, lack, secret, privacy, friendship 